\title{
Strengthening of work-life balance while working remotely in the context of COVID-19 pandemic
}

\author{
Živilè Stankevičiūtè ${ }^{\mathrm{a}, *}$ and Svetlana Kunskaja ${ }^{\mathrm{b}}$ \\ ${ }^{a}$ School of Economics and Business, Kaunas University of Technology, Kaunas, Lithuania \\ ${ }^{\mathrm{b}}$ Kaunas University of Technology, Kaunas, Lithuania
}

Received 29 June 2021

Accepted 24 November 2021

\begin{abstract}
.
BACKGROUND: Recently, quite a number of employees have been asked to choose remote work or even have been forced into it as a result of the COVID-19 pandemic. Notwithstanding the benefits suggested by remote working, e.g. saving on commuting time and expenses working from home generates numerous challenges for employees, including the blurred line between the roles of working and private life. While, previous studies have demonstrated that work-life balance, which refers to the ability of every individual to coordinate work and family obligations successfully, has a significant impact on employee well-being and organisational performance, ways for maintaining the balance under crisis remain underexplored.

OBJECTIVE: Trying to narrow the gap, the paper aims at revealing the antecedents of work-life balance while working remotely during the COVID-19 pandemic.

METHODS: A quantitative survey has been conducted in Lithuania (pilot study). The data have been collected from the employees working only remotely.

RESULTS: The results provided evidence that employees struggled with work-home balance while working remotely. In line with the results, work and family demands served as detrimental factors for work-home balance, while manager support, co-workers support, job autonomy, and job control increased work-home balance.

CONCLUSIONS: Thus, the research results expand the knowledge on the antecedents of work-life balance in a crisis situation. Moreover, the findings have significant implications for employers demonstrating that organisations need to carefully plan and implement new strategies and practices for work-home balance improvement for the employees who work from home.
\end{abstract}

Keywords: Work-life balance, remote work, COVID-19, crisis situation, work-life balance antecedents

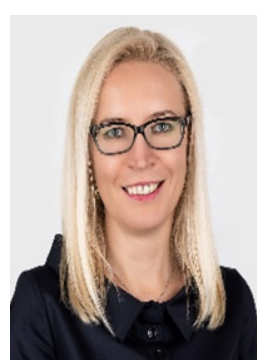

Živilè Stankevičiūtè , $\mathrm{PhD}$ in Management, is an associate professor at Sustainable Management research group, School of Economics and Business, Kaunas University of Technology, Lithuania. Her doctoral dissertation on Sustainable Human Resource Management has been recognised internationally: she got Baltic University Programme Annual Award for the Best PhD defended in 2015. Her research interests are: Sustainable Human Resource Management, Employee Wellbeing,
Digital Transformations, Corporate Social Responsibility, Sustainable Development. She is a member of National Expert Council for sustainable development goals at Lithuanian Responsible Business Association (LAVA) dealing with SDG8. She is also a member of AOM (Academy of Management), International Sustainable Development Research Society (ISDRS), EURAM (European Academy of Management). Lecturing includes courses on Sustainable Development, Employee Performance Management, Human Analytics. She has expertise in the field of partnership with business while conducting research projects and providing the practical implications based on research quantitative and qualitative data. In 2019 and 2020, she got Kaunas University of Technology Award as the Most Active Young Researcher.

\footnotetext{
${ }^{*}$ Corresponding author: Živile Stankevičiūte, Kaunas University of Technology, School of Economics and Business, Gedimino g. 50, Kaunas, Lithuania. E-mail: zivile.stankeviciute@ktu.lt.
} 


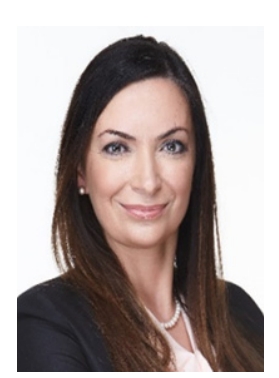

Svetlana Kunskaja is $\mathrm{PhD}$ student of the joint doctoral studies between Lithuanian Energy Institute, Kaunas University of Technology and Klaipeda University. Her research interests are: Employee Wellbeing, Corporate resonsibility, Sustainable Development, Sustainable Consumption. Svetlana has accumulated professional experience at international and Lithuanian companies. Her main duties revolved around staff management and administration; procurements, project administration and coordination; also business organisation and administration. Svetlana has a Master's degree in Business and Management.

\section{Introduction}

The COVID-19 pandemic caused a relocation of workplaces to the homes of employees [1-3]. This situation sets forth the work-life balance (WLB) challenges as remote employees are faced with blurred work and nonwork duties [4]. It is indicated by a number of studies that remote work creates such benefits as saving on commuting time and expenses, flexible scheduling and work-from-home opportunities [5, 6]. However, remote work also serves as a source of negative impact on employees as it interferes with the places and time that should be dedicated to personal life [6]. In turn, this may lead to weakening of WLB. Remote work turned into a necessity for many of us due to the COVID-19 pandemic [1, 5], but the ways of maintaining WLB in the face of crisis remain underexplored, due to concentration of previous studies regarding remote work and WLB on the knowledge accumulated before the pandemic [7]. For the purposes of narrowing the gap the present paper addresses the factors that might be relevant from WLB perspective. The aim of the paper is to reveal the antecedents of WLB while working remotely during the COVID-19 pandemic. Thus, a quantitative survey has been conducted in Lithuania (pilot study). The data have been collected from the employees working only remotely under lockdown conditions. The paper contributes to literature in several ways. Firstly, the COVID-19 pandemic context presents a unique opportunity to study some of the tenets, related to finding WLB under the crisis conditions. It is possible to reveal the employees' attitudes towards remote work, WLB, and a potential way of strengthening WLB in the lockdown situation. Such findings contribute to the literature on well-being of employees as it deals with the behaviour of and assistance to employees in unforeseen situations. Secondly, the paper adds values to the literature on human resources management as it explores the ways of increasing WLB while tackling family and organisational factors. Thirdly, the paper enriches the ideas on what is relevant for employees while working remotely. Thus, the above ideas might serve as recommendations for practicians. The remaining sections of the paper is structured as follows: the theoretical part gives an overview of the literature on working remotely, WLB, the main antecedents of WLB. Later, the hypotheses are developed. Further, the applied research method is described. Then, the empirical results and discussion come further. Finally, the conclusions are drawn.

\section{Literature review and Hypotheses}

\subsection{Working remotely during COVID-19}

Academic interest in remote work (also referred to as teleworking, telecommuting, distributed work, or flexible work arrangements) [8] has been steadily growing in recent years [5, 6, 9-13]. This paper follows the view of Di Martino and Wirth (1990) defining remote working as "a flexible work arrangement whereby workers work in locations, remote from their central offices or production facilities, the worker has no personal contact with co-workers there, but is able to communicate with them using technology" [14, p. 530].

According to Lapierre et al. [13], under normal conditions, remote work is usually a voluntary option, chosen by workers themselves [5]. And now it has become a must. Before the pandemic, however, remote work has not been that common [5, 15]. Results of the survey conducted by Eurofound in 2017 pointed to the EU average of $18 \%$ and the Lithuanian average of $13 \%$ employees working outside their offices under normal conditions ([6, 7]. In addition to that, Wang et al. [15] emphasize the remote work as a privilege mostly enjoyed by highly-educated employees, earning higher-thanaverage income before the pandemic. COVID-19 has turned lifestyles and employment upside-down all over the world. The lockdown has forced all kinds of organisations to digitise their activities with education at universities, schools, and kindergartens moving online, an instant growth in the demand for 
e-commerce and mail delivery services, and office workers settling into their virtual workspaces at home [7]. For the reason of changes in the previously stable activities, remote work may have a positive or negative impact on WLB for every employee and lead to different results, since WLB is a return to one's life values and priorities [16]. For example, on one hand, for some people working remotely can enrich the quality of relationships with their families. On another hand, working from home can enlarge the blurring of lines between work and family, making the endeavours to divide time for work and time for family more difficult [16].

\subsection{Work-life balance}

In recent decades, the public discourse used to focus a lot of attention on WLB [6, 17-20, 80]. The term itself illustrates how well people manage to handle their work with professional responsibilities, and their personal responsibilities, lifestyle, values and goals [18, 20, 21]. In other words, WLB is a person's ability to balance work needs with their personal and family needs. The researchers agree that when individuals are satisfied with the roles of work and private life, WLB can be considered successful. Greenhaus et al. [22] defined a parameter of work-family balance based on "three specific components: time balance (equal time between work and family roles), involvement balance (equal psychological involvement in work and family roles) and satisfaction balance (equal satisfaction with work and family roles)" (p. 513). Thus, in general, the absence of conflict between different roles, psychological satisfaction, managing the balance between daily activities at work and not at work, the ability to reconcile work and family roles, and devoting time to oneself are the combination that best defines the right WLB $[6,20,23]$. The added value of WLB for employees and the organisations is not arguable. WLB is very important in increasing the quality of work satisfaction [24], psychological wellbeing [25], employee commitment [26], social life [27] and other aspects [3]. Despite the significance of WLB, exhaustive studies on the topic of WLB are missing [23]. Moreover, only a few researchers have attempted to study how to manage WLB in the times of crisis, such as COVID-19 pandemic. Meanwhile, Kumar and Mokashi [3] assume that an on-going pandemic will continue to damage WLB all over the world. Having the significance of WLB in mind, the antecedents of WLB are highly important.

\subsection{Antecedents of work-life balance and hypotheses}

The literature on the work-family link has highlighted several factors contributing to WLB, either positively or negatively. Based on the research studies $[23,28-30]$ a briefly review of antecedents of WLB has been conducted whether top management commitment \& involvement (family-friendly benefits, work/life programs, work/life initiatives and polices, work/family culture, supervisor support, co-worker help and support); hours of work (annualized hours, compressed hours, flexi-time, overtime, number of hours worked per week); work schedule (job-share, working from home, teleworking/e-working, job autonomy, job control); employees responsibilities (child care, caring for dependents, number of children living together, marital status); leaves and vacations (emergency leaves, paid annual leaves, unpaid leaves, maternity leaves, career break/study leaves), are likely to increase or decrease individuals' perception of WLB.

In this paper two clusters of antecedents are explored: demands related to the work scope and demands related to the family scope. It was stated that both scopes may influence a person's understanding of WLB, because perception of higher demands from these two important domains in a person's life may prevent one from participation in other life roles. Based on previous studies [23, 28-30] pertaining to the work scope the focus used to be directed to work-related antecedents: work demands, number of hours worked per week, overtime, job autonomy, supervisor support, co-worker help and support, and job control. In the family scope the focus was directed to family-related antecedents: family demands; number of children living together and learning remotely; number of adults working remotely while living in the same home.

Further the hypothesis linking WLB and their antecedents are presented.

Work demand and WLB. Work demands refer to a perceptual concept, which covers a general understanding of individual work roles and responsibilities. Work demands include pressures, caused by the employee (e.g., the desire or motivation to achieve certain work or personal goals), work environment (e.g., level of responsibilities assigned) [23], additional stress because of excessive workloads and working time (e.g. approaching deadlines) [31]. According to the studies conducted before, work demands increase work-family conflict (WFC) 
[32] and are detrimental to work-family enrichment (WFE) [33]. Nordenmark et al. [34] identified work demands having a negative relationship to WLB. Work demands, such as daily working hours and work pressure have a negative relationship with WLB [31]. Byron [35] believes that work demands and work-family conflict do not show any significant relationship. O'Driscoll, Brough and Biggs [36] and Brough, O'Driscol, and Kalliath [37] also studied the effect of work demands on work-family conflict and came to similar conclusions. Going further, higher work demands (e.g. working time, workload, or irregular work schedules) could be associated with a lower WLB [38]. Haar et al. [23] found the relationship between work demands and work-family balance being negative. This means that work demands generally have a negative effect on the employees' attempts to balance their work and personal lives. Accordingly, the paper hypothesizes the following:

H1: Work demands will be negatively related to WLB.

Number of hours worked per week and WLB. Balance means allocation of equal time to one's career, family and other aspects of life [39]. People may report huge differences in WLB levels even if they work the same number of hours [30], but a previous research has indicated a negative effect of daily working hours on WLB [40]. As for balance, long working hours may reduce the time to be spent for non-workrelated activities [31]. Since they draw on a limited energy resource, long working hours may eventually lead to a depletion of resources [30]. Sturges and Guest [41] found the relationship between the number of hours worked per week and work/non-work conflict to be positive, while Valcour [17] stated the relationship between the number of hours worked per week and the work-family balance to be negative. Therefore, the following hypothesis is offered:

$\mathrm{H} 2$ : The number of hours worked per week will be negatively related to WLB.

Overtime and WLB. WLB may be disrupted by individual choices, such as working overtime, which includes bringing work home, working and answering emails after working hours, on weekends and holidays [42]. These habits may be common for those, who have flexible work arrangements, eventually resulting in overtime and poorer WLB [42]. During earlier studies, Bjärntoft et al. [43] found WLB negatively influenced by overtime work. One of the reasons is, that often expected to be available outside normal working hours, employees may find it difficult to stay away from work issues after the workday is over, resulting in longer working hours than usual and a disrupted WLB. The dominance of work demands overtime hours thus confirming the role balance theory [18]. This approach focuses on an employee's time management abilities instead of how much time a certain work role actually needs. Overtime takes away off-work time, while intensive work and work-related stress could lead to fatigue, anxiety or other negative physiological consequences, which also have a negative influence on the quality of home and family life [21]. Consequently, the following hypothesis is formulated:

H3: Overtime will be negatively related to WLB.

Job autonomy and WLB. Job autonomy is referred to as the possibility to decide on the ways to carry out one's work, creating a sense of control [44]. It is important to ensure unavailability of any unnecessary restrictions [45], such as constant monitoring by a supervisor. According to Haar et al. [23], job autonomy is an important resource to ensure an individual's WLB. Earlier work-life research indicated job autonomy as an important condition to achieve greater well-being and lower stress levels. Many similar studies emphasize the importance of job autonomy in promoting positive employee results [44]. Vera et al. [46] believe job autonomy to be a vital resource, which could help employees achieve the level of WLB that they want. For instance, being able to control their schedule, employees can freely manage their time, resulting in a more efficient implementation of their work and non-work responsibilities [47]. According to Carvalho and Chambel [48], job autonomy increases work-family enrichment, because being able to control the performance of their work, it can encourage employees to develop further skills, which nay potentially result in benefits to family performance. This means that having job autonomy and working for a supportive boss can increase individual understanding of arranging work and family demands, and resources at their disposal, which, in turn, results in a positive effect on an individuals' sense of balance [23]. Accordingly, the following hypothesis is formulated:

H4: Job autonomy will be positively related to WLB.

Supervisor support and WLB. The key aspects here include support at work [3] and facilitation, while understanding from the immediate supervisor 
seems to be vital in boosting individual behaviours and results $[49,50]$. Supervisor support may also become even more important when employees must take up various challenges, especially in balancing their work life issues during COVID-19. Employee behaviours and results have always been significantly influenced by any amount of support at an organizational level [51, 52]. Supervisor support means that the workplace recognizes and appreciates its employees, looking for ways to make work easier [3]. Moreover, according to a recent study by Winarto and Chalidyanto [53], employee job satisfaction is highly dependent on supervisor support. This reaffirms that supervisor support at work is vital in connection to WLB [23]. According to previous research, supervisor support is an important resource, which could determine the individual abilities to achieve WLB. Supervisor support is associated with lower levels of work-family conflict [54], higher levels of work-family enrichment $[48,55]$ and more life satisfaction [56]. Supervisors may help their employees combine their work and non-work roles by offering emotional and instrumental support, being a rolemodel, and finding creative approaches to managing work and family demands of their employees $[57,54]$. Supervisor support has a strong and positive relationship with WLB and can help employees find a balance between their work with other life roles [23]. The following hypothesis is suggested:

H5: Supervisor support will be positively related to WLB.

Co-worker help and support and WLB. Previous studies have highlighted the importance of co-worker help and support in organizations [59]. For example, Ferguson et al. [58] identified a link between co-worker help and support, and greater satisfaction through WLB. Co-worker help and support evidence indicates clear links towards better WLB [59]. Based on theories of organizational justice, there is an evidence suggesting that resentment by work colleagues may contribute to a negative work environment where work-life policies are not encouraged by co-workers [60]. A study by Lu et al. [61] examined the effect of family-friendly co-workers and identified a positive relationship with work-family and family-work facilitation. A meta-analysis research conducted by Michel et al. [62] replicated the previous empirical findings and identified co-worker help and support associated with work-family and family-work facilitation. Bradley et al. [59] confirmed the previous research and concluded that co-worker help and support in relation to WLB was positively related to employee wellbeing. That kind of support made balancing work and life better [59]. Thus, the following hypothesis is formulated:

H6: Co-worker help and support will be positively related to WLB.

Job control and WLB. Job control refers to an employees' perceived ability to finish their tasks, using their own decision, skills and knowledge [63]. Job control means that an employee being free to make individual decisions on doing certain jobrelated tasks, picking the most appropriate time and methods [64]. Previous studies have concluded job control to be positively related to WLB [23]. A significant influence of job control on WLB and resulting positive effects on work/personal life enhancement have also been discovered by Lee-Peng et al. [65]. The analysis of Nordenmark, Vinberg \& Strandh [34] replicated the previous empirical findings concluding that job control had a generally positive relationship to WLB. Based on this, the following hypothesis is formulated:

H7: Job control will be positively related to WLB.

Family demands and WLB. Family demands include such aspects as individual roles in the family (e.g. father, mother, etc.), family responsibilities (e.g. childcare, house chores, etc.), looking after senior members and children. There are also some other demands in WLB, such as relaxing, going on holidays, sports and taking part in personal development programmes [21]. Organisations expect their employees to dedicate more time for their work, while family members expect the same in terms of family matters. People that are unable to find WLB eventually encounter many family problems, such as lower family satisfaction or lack of involvement in family roles [21]. Family demands include caring for other family members - usually children and senior family members [66], and these demands contribute to a higher work-family conflict and a lower work-family enrichment [67]. Studies on the relationship between work and family also show that having children at home can increase the work-family conflict $[35 ; 41]$. Based on this, the following hypothesis is formulated:

H8: Family Demands will be negatively related to WLB.

Number of children living together and learning remotely and WLB. As women more active involvement in labour market $[68,69]$, family support [70] 
and gender aspects referring to mothers and fathers duties has an impact on WLB [71-73], not suprising children also play some rule [74-76]. The study of Esteves et al. [77] showed that having to juggle work and childcare and/or home-schooling during lockdown had a negative impact on WLB. WLB in families with children (12 years or younger) is lower than in families with no children. A greater negative effect can also be felt in families with younger children. The following hypothesis is suggested:

H9: Number of children living together and learning remotely will be negatively related to WLB.

Number of adults working remotely while living in the same home will be negatively related to WLB. During the COVID-19 outbreak, working individuals faced a bigger challenge between work and family balance [15]. The study by Wang et al. [15] reveals that a set of challenges in remote working during the pandemic "negatively affect individuals' work effectiveness and well-being" (p. 31), because working remotely means more "interruptions from family, which may negatively influence" (p. 28). While individuals are working remotely, family members can make noise, interrupt with non-work issues and this will be a consistent reminder that the employee is at home rather than at the workplace [4]. This could make people feel exhausted. Moreover, sharing a workplace and a home with the same people could bring difficulties in balancing work and family lives [4]. More household members who share the home with the worker, more challenging it can be for the employees who prefer to have work-nonwork boundaries that meet their own needs [4]. To establish time boundaries is easier for those who live alone than those who live with others [4]. Based on previous research, the number of other individuals working remotely at home may negatively impact the WLB [4]. Thus, the following hypothesis is formulated:

H10: Number of adults working remotely while living in the same home will be negatively related to WLB.

\section{Methodology}

\subsection{Sample and data collection}

Given the objective of the research, data were collected by using a convenience sampling type from employees (who had an employment contract) in
Lithuania working only remotely during the COVID19 lockdown. Convenience sampling is a type of non-probability sampling where members of the target population who meet certain practical criteria, such as availability at a given time, easy accessibility, geographical proximity, or the willingness to participate are included for the purpose of the study [78].

For the survey, an online questionnaire was created. The questionnaire was distributed via LinkedIn, Facebook, and other social networks. Participants were also asked to share the questionnaires with their colleagues and friends. Due to the way of questionnaire dissemination, it is impossible to estimate the number of persons the questionnaire was sent to and the response rate. While distributing the questionnaire, the information about the purpose of the survey and the link to the survey were enclosed. The first question was related to the nature of work. The possibility to continue the survey was provided only in case of answering that they worked under an employment contract during the lockdown only remotely. It should be acknowledged that a certain number of employees who worked remotely was not reached as not all respondents who worked remotely use social media. Due to this fact the paper does not claim for a full representation of employees who worked remotely during lockdown."

Data collection took approximately 2 months (April to May, 2021). By the end of the inquiry 305 questionnaires were collected and according to the number of the employed population in Lithuania, the collected number of responses reflected an acceptable bias of $5.5 \%$, which indicated the reliability of the data. The respondents to the survey had to reflect the target group: the working people who had the opportunity to work remotely. Out of the total number of 305 respondents $73.8 \%$ were females and $26.2 \%$ males. $57.4 \%$ of participants were born between 1982 and 2000. Family size/number of children learning remotely accounted for $18.4 \%$ with one child and $22.6 \%$ with two children. (Pls. ref. to Table 1).

\subsection{Measurement scales}

A self-reported questionnaire was used. WLB was measured using a 3-item measure designed by Haar [79]. Work demands were evaluated using three items developed by Haar [23]. Job autonomy was measured using four items developed by Knudsen et al. [80]. Supervisor support was rated using three items from Lambert [81]. Co-worker help and support were 
Table 1

Profile of the survey respondents

\begin{tabular}{|c|c|c|c|}
\hline & Response categories & $n$ & $\%$ \\
\hline \multirow[t]{2}{*}{ Gender } & Male & 80 & 26.2 \\
\hline & Female & 225 & 73.8 \\
\hline \multirow[t]{4}{*}{ Generation } & 2001 or later & 5 & 1.6 \\
\hline & $1982-2000$ & 175 & 57.4 \\
\hline & $1961-1981$ & 110 & 36.1 \\
\hline & $1943-1960$ & 15 & 4.9 \\
\hline \multirow[t]{9}{*}{ Education } & $\begin{array}{l}\text { Unfinished secondary } \\
\text { education }\end{array}$ & 2 & 0.7 \\
\hline & Secondary & 26 & 8.5 \\
\hline & Vocational & 4 & 1.3 \\
\hline & Higher Education & 3 & 1.0 \\
\hline & College & 23 & 7.5 \\
\hline & Bachelor Degree & 82 & 26.9 \\
\hline & Master Degree & 112 & 36.7 \\
\hline & Doctoral Degree & 52 & 17.0 \\
\hline & Others & 1 & 0.3 \\
\hline \multirow[t]{6}{*}{ Work experience } & up to 1 year & 60 & 19.7 \\
\hline & from 1 to 3 years & 74 & 24.3 \\
\hline & from 3 to 5 years & 53 & 17.4 \\
\hline & from 5 to 10 years & 46 & 15.1 \\
\hline & from 10 years to 20 years & 42 & 13.8 \\
\hline & more than 20 years & 30 & 9.8 \\
\hline \multirow{6}{*}{$\begin{array}{l}\text { Family size/number } \\
\text { of children learning } \\
\text { remotely }\end{array}$} & I have no children & 129 & 42.3 \\
\hline & Neither & 33 & 10.8 \\
\hline & One & 56 & 18.4 \\
\hline & Two & 69 & 22.6 \\
\hline & Three & 15 & 4.9 \\
\hline & Four & 3 & 1.0 \\
\hline Total & & 305 & 100 \\
\hline
\end{tabular}

examined using four items proposed by $\mathrm{Li}$ and Liu [82]. Job control was measured using five items by Millán et al. [64]. Family demands were measured using three items by Haar et al. [23]. All these variables were measured on a five-point Likert-type scale where 1 indicated "strongly disagree", and 5 indicated "strongly agree".

The number of hours worked, following Spector et al. [83], was measured using a single item "How many hours do you work in a typical week?" Overtime was measured using an item by Haar et al. [23]: "How many overtime hours do you work in a typical week?". All items were translated into the Lithuanian language using a back translation procedure [84], ensuring translation accuracy.

There was a question about the number of adults working remotely and living in the same home and a question about the number of children living together and learning remotely. The demographic characteristics such as gender, age, education, and working experience were taken into account.

\section{Results}

Regarding the data analysis, a factor analysis was performed. Factor analysis operates on the notion that "measurable and observable variables can be reduced to fewer latent variables that share a common variance and are unobservable, which is known as reducing dimensionality" [85, p.80]. The results of the factor analysis are shown in Table 2.

Later, the reliability value for each construct was calculated using Cronbach's alpha. Accordingly, Cronbach's alpha was for WLB was $\alpha=0.917$; for work demands - $\alpha=0.880$; for job autonomy $-\alpha=0$. 859 ; for supervisor support $-\alpha=0.878$; for coworker help and support - $\alpha=0.890$; for job control $\alpha=0.810$; and for family demands $-\alpha=0.911$. Thus, all measures were subjected to reliability analysis. As all Cronbach's alpha coefficients exceeded 0.7, all measures were considered acceptable for the analysis [86].

The means, standard deviations, and correlation matrix are provided in Table 3. Referring to Table 3, a negative correlation between work demands and WLB $(-0.371, p<0.01)$ has been revealed. The same situation is observed in respect to family demands, where a negative correlation between family demands and WLB $(-0.388, p<0.01)$ has been identified. The correlation between job autonomy and WLB (0.280, $p<0.01)$ has been found positive. Also, a positive correlation between supervisor support and WLB $(0.263, p<0.01)$ is discovered. With reference to job control, a positive correlation between job control and WLB $(0.256, p<0.01)$ is revealed. The correlation between co-worker help and support and WLB $(0.206, p<0.01)$ is also positive. Concerning the number of hours worked per week, a negative correlation between the number of hours worked per week and WLB $(-0.179, p<0.01)$ is identified. The same situation has been discovered between overtime and WLB $(-0.210, p<0.01)$, where the correlation is negative. Referring to Table 3, statistically significant relationship between the number of children living together and learning remotely and WLB has not been found. The same situation is observed in respect to the number of adults working remotely while living in the same home, seeing that statistically significant 
Table 2

Rotated Component Matrix

\begin{tabular}{|c|c|c|c|c|c|c|c|}
\hline \multirow[t]{2}{*}{ Items } & \multicolumn{7}{|c|}{ Component } \\
\hline & 1 & 2 & 3 & 4 & 5 & 6 & 7 \\
\hline I am satisfied with my WLB, enjoying both roles & 0.938 & & & & & & \\
\hline Nowadays, I seem to enjoy every part of my life equally well & 0.936 & & & & & & \\
\hline I manage to balance the demands of my work and personal life well & 0.903 & & & & & & \\
\hline I am given too much work to do & & 0.926 & & & & & \\
\hline I have more work than I can do well & & 0.901 & & & & & \\
\hline I often feel that I am being run ragged' & & 0.868 & & & & & \\
\hline I can decide how I do my work & & & 0.849 & & & & \\
\hline My job allows me freedom to decide how I do my own work & & & 0.847 & & & & \\
\hline I take part in job decisions that affect me & & & 0.829 & & & & \\
\hline I have a lot to say over what happens on my job & & & 0.821 & & & & \\
\hline $\begin{array}{l}\text { My supervisor is understanding when I have personal or family problems } \\
\text { which interfere with my work }\end{array}$ & & & & 0.914 & & & \\
\hline My supervisor is helpful when I have a personal emergency & & & & 0.892 & & & \\
\hline My supervisor is concerned about me as a person & & & & 0.886 & & & \\
\hline My co-workers encourage each other when someone feels down & & & & & 0.895 & & \\
\hline My co-workers try to act like peacemakers when there are disagreements & & & & & 0.868 & & \\
\hline $\begin{array}{l}\text { My co-workers will help each other out if someone falls behind in his/her } \\
\text { work }\end{array}$ & & & & & 0.864 & & \\
\hline My co-workers willingly share their expertise with each other & & & & & 0.841 & & \\
\hline $\begin{array}{l}\text { Ability to choose or change (i) order of tasks, (ii) methods of work and (iii) } \\
\text { speed or rate of work }\end{array}$ & & & & & & 0.805 & \\
\hline Ability to apply one's ideas at work & & & & & & 0.793 & \\
\hline Capacity to influence important decisions at work & & & & & & 0.736 & \\
\hline Ability to take a break when wished & & & & & & 0.732 & \\
\hline Capacity to set one's work schedule & & & & & & 0.715 & \\
\hline It is difficult to do all I should do as a family member & & & & & & & 0.936 \\
\hline I have more house/family work to do than I can do well & & & & & & & 0.918 \\
\hline My family/home duties leave me feeling tired & & & & & & & 0.910 \\
\hline
\end{tabular}

Notes: 1 - WLB; 2 - work demands; 3 - job autonomy; 4 - supervisor support; 5 - co-worker support; 6 - job control; 7 - family demands.

relationship between the number of adults working remotely while living in the same home and WLB has not been found. Regarding this, the hypotheses $\mathrm{H} 9$ and $\mathrm{H} 10$ were not confirmed and were rejected.

Further, to test the study hypotheses, multiple regression analyses have been conducted (Table 4). The results are discussed further.

It can be seen from Table 4 that hypotheses H4, H5, H6 and H7 were supported seeing that a positive relationship was found between job autonomy and WLB $(0.323, p<0.05)$, supervisor support and WLB $(0.273, p<0.01)$, co-worker support and $\operatorname{WLB}(0.257, p<0.01)$, job control and WLB $(0.263$, $p<0.01)$. The hypotheses $\mathrm{H} 1, \mathrm{H} 2, \mathrm{H} 3$ and $\mathrm{H} 8$ were supported seeing that a negative relationship was found between work demands and WLB $(-0.364$, $p<0.01)$, number of worked hours and WLB $(-0.232$, $p<0.01)$, overtime and WLB $(-0.262, p<0.05)$, family demands and WLB $(-0.406, p<0.01)$.

\section{Discussion}

The aim of this research was to examine antecedents of WLB while working remotely during the COVID-19 pandemic. In doing this, a pilot study was conducted. It was found that work demands, the number of hours worked, overtime and family demands were negatively related to WLB, while alternatively, greater job autonomy, supervisor support, co-worker help and support, and job control enhance WLB. It has not been found statistically 
Table 3

Means, standard deviations, and correlations matrix

\begin{tabular}{|c|c|c|c|c|c|c|c|c|c|c|c|c|}
\hline & Mean & Std & 1 & 2 & 3 & 4 & 5 & 6 & 7 & 8 & 9 & 10 \\
\hline 1. WLB & 3,2667 & 1,07143 & & & & & & & & & & \\
\hline 2. Work demand & 2,8612 & 1,02849 & $-0,371^{* *}$ & & & & & & & & & \\
\hline $\begin{array}{l}\text { 3. Number of hours worked per } \\
\text { week }\end{array}$ & 3,06 & 2,187 & $-0,179^{* *}$ & $0,267^{* *}$ & & & & & & & & \\
\hline 4. Overtime & 2,33 & 1,624 & $-0,210^{* *}$ & $0,339^{* *}$ & $0,674^{* *}$ & & & & & & & \\
\hline 5. Job autonomy & 3,5885 & 0,85404 & $0,280^{* *}$ & $-0,193^{* *}$ & 0,026 & $-0,004$ & & & & & & \\
\hline 6. Supervisor support & 3,7049 & 0,87128 & $0,263^{* *}$ & $-0,209^{* *}$ & $-0,075$ & $-0,152^{* *}$ & $0,513^{* *}$ & & & & & \\
\hline 7. Co-worker help and support & 3,6574 & 0,81630 & $0,206^{* *}$ & $-0,123^{*}$ & $-0,046$ & $-0,134^{*}$ & $0,335^{* *}$ & $0,485^{* *}$ & & & & \\
\hline 8. Job control & 3,6505 & 0,76671 & $0,256^{* *}$ & $-0,237^{* *}$ & $0,128^{*}$ & 0,053 & $0,712^{* *}$ & $0,400^{* *}$ & $0,336^{* *}$ & & & \\
\hline 9. Family Demands & 2,8011 & 1,10147 & $-0,388^{* *}$ & $0,481^{* *}$ & 0,080 & $0,119^{*}$ & $-0,070$ & $-0,062$ & $-0,004$ & $-0,087$ & & \\
\hline $\begin{array}{l}\text { 10. Number of children living } \\
\text { together and learning remotely }\end{array}$ & 2,40 & 1,399 & $-0,014$ & $-0,082$ & $0,138^{*}$ & 0,083 & 0,088 & $-0,009$ & $-0,063$ & $0,150^{* *}$ & $0,157^{* * *}$ & \\
\hline $\begin{array}{l}\text { 11. Number of adults working } \\
\text { remotely while living in the same } \\
\text { home }\end{array}$ & 1,48 & 0,607 & 0,001 & 0,067 & $0,121^{*}$ & $0,151^{* *}$ & 0,043 & 0,011 & $-0,049$ & $0,127^{*}$ & $-0,012$ & $0,116^{*}$ \\
\hline
\end{tabular}

Table 4

Regression analysis

\begin{tabular}{|c|c|c|c|c|c|c|c|c|}
\hline & \multicolumn{8}{|c|}{ Dependent Variable: (Standardised $\beta$ ) } \\
\hline & $\begin{array}{l}\text { WLB } \\
(\mathrm{H} 1)\end{array}$ & $\begin{array}{l}\text { WLB } \\
(\mathrm{H} 2)\end{array}$ & $\begin{array}{l}\text { WLB } \\
(\mathrm{H} 3)\end{array}$ & $\begin{array}{l}\text { WLB } \\
(\mathrm{H} 4)\end{array}$ & $\begin{array}{l}\text { WLB } \\
(\mathrm{H} 5)\end{array}$ & $\begin{array}{l}\text { WLB } \\
(\mathrm{H} 6)\end{array}$ & $\begin{array}{l}\text { WLB } \\
(\mathrm{H} 7)\end{array}$ & $\begin{array}{l}\text { WLB } \\
(\mathrm{H} 8)\end{array}$ \\
\hline \multicolumn{9}{|l|}{ Control variables } \\
\hline Gender & $-0,011$ & $-0,062$ & $-0,056$ & $-0,003$ & $-0,057$ & $-0,057$ & $-0,028$ & 0,032 \\
\hline Age & 0,015 & 0,056 & 0,055 & 0,035 & 0,044 & 0,000 & $-0,008$ & 0,045 \\
\hline Education & 0,004 & 0,042 & 0,035 & $-0,039$ & $-0,006$ & 0,002 & $-0,021$ & 0,004 \\
\hline Time worked for the organisation & $-0,027$ & 0,020 & 0,034 & 0,026 & 0,032 & 0,047 & 0,023 & $-0,046$ \\
\hline \multicolumn{9}{|l|}{ Constructs } \\
\hline Work demands & $-0,364^{* * *}$ & & & & & & & \\
\hline Number of worked hours & & $-0,232^{* * *}$ & & & & & & \\
\hline Overtime & & & $-0,262^{* *}$ & & & & & \\
\hline Job autonomy & & & & $0,323^{* *}$ & & & & \\
\hline Supervisor support & & & & & $0,273^{* * *}$ & & & \\
\hline Co-worker support & & & & & & $0,257^{* * *}$ & & \\
\hline Job control & & & & & & & $0,263^{* * *}$ & \\
\hline Family demands & & & & & & & & $-0,406 * * *$ \\
\hline $\mathrm{R} 2$ & 0.133 & 0.055 & 0.069 & 0.105 & 0.078 & 0.066 & 0.070 & 0.161 \\
\hline Total F & 9.137 & 3.454 & 4.422 & 7.053 & 5.042 & 4.241 & 4.496 & 11.447 \\
\hline Adjusted R2 & 0.188 & 0.039 & 0.053 & 0.091 & 0.062 & 0.051 & 0.054 & 0.147 \\
\hline
\end{tabular}

${ }^{* * *} p<0.01 .{ }^{* *} p<0.05 .{ }^{*} p<0.1$.

significant relationship between the number of children living together and learning remotely and WLB and between the number of adults working remotely while living in the same home and WLB. Turning to the linkage between work demands and WLB, the current study replicated the previous empirical findings on negative effect [30]. Haar \& Brougham [30] collected data from 80 organizations in various industries and judging from the results, work demands impair the WLB. In this study it has been revealed 
that the number of hours worked per week were universally harmful for the employees to achieve a higher WLB. This aligns with other studies examining negative relationship between the number of hours worked per week and the WLB [17]. This research by Valcour [17] reports an investigation of the relationships of work hours, job complexity, and control over work time to satisfaction with workfamily balance based on data from a sample of 570 telephone call center representative. The results indicated that overtime might be detrimental to WLB. The findings support studies having found overtime to be detrimental to WLB of employees [42]. Mellner, Aronsson \& Kecklund [42] collected data at a large Swedish telecom company and revealed that job autonomy was strongly and positively related to WLB. These findings complement previous studies where job autonomy enhance WLB [23]. Turning to the linkage between supervisor support and WLB, the current research replicated the previous empirical findings on positive effect. Based on the findings, supervisor support improves WLB [23]. Moreover, the results also indicate that co-worker help and support, and job control positively relate to WLB. These findings support to the findings of the previous research by Russo, Shteigman \& Carmeli [70] that explore the ways in which multiple support sources (workplace and family social support) help individuals to experience WLB across three population groups in Israel (part-time students, cross-sectional data from workers in the industrial sector and physicians in public hospitals). Regarding job control, the derived results demonstrate that job control is valued as a contextual resource that can help employees to keep positive balance between work and other life roles. This is in line with other studies examining the positive impact of job control on WLB [23]. The results also indicate that family demands are negatively related to WLB. The results indicate the findings of previous studies suggesting that family demands can have a detrimental effect on WLB [66].

Having in mind the sample of the research $(73.8$ $\%$ were women), it is worth to discuss the findings in relation to gender aspects. Previous literature has concluded that men and women use flexible working in different ways as women generally continue doing more household work than their male partners [87]. Although women and men equally perceive the domestic tasks needing to be done, men are more likely to ignore these responsibilities, leaving them to their female partners [88]. As such, remote work adds more duties for women [73]. Therefore, previous studies warn that "working at home does not actually improve the quality of women's working life but boosts traditional gender roles" [89, p. 11]. Turning to the current research, WLB was evaluated higher that average (mean score 3.2667). It could be predicted that women try to demonstrate as the best possible WLB, even acknowledging that family demands serve as the highest detrimental factor $(-0.406, p<0.001)$ for WLB. Still, in order to make further conclusions on gender, WLB, remote work quality and intensity, and career prospects, further studies are needed.

Finally, based on previous literature it should be admitted that working remotely might cause dual (positive and negative) consequences regarding WLB [90]. Although freedom and flexibility to do the work at anytime and anywhere might strengthen WLB [90], the achievement of WLB might be more difficult while working remotely as the borders between home and work are intentionally blurred [89]. This might be even more difficult in times of crisis.

Summing up, the findings contribute to literature by providing empirical evidence on antecedents of WLB while working remotely and by calling to further scientific discussion on the impact of remote work on WLB.

\section{Conclusions}

The aim of the paper was to explore the antecedents of WLB while working remotely under the COVID19 pandemic situation. The findings confirmed that such job resources, as job autonomy, job control, supervisor support, and co-worker support served as factors enhancing WLB. More specifically, possibility to enjoy independence, discretion, and freedom in the day-to-day work [91], having control over work processes [92] or counting on supervisor's or co-worker'help and support help achieving balance between the demands of work and private life. Meanwhile, such job demands like work demands, number of worked hours, and overtime, on the contrary, led to lower WLB. Moreover, the findings demonstrated the crucial role of family demands in shaping WLB as higher family demands determined lower WLB. Treating WLB as beneficial for both organisations and employees in short- and long-term perspectives, organisations are encouraged to implement such human resource management practices that could contribute to higher WLB. 


\subsection{Practical implications}

The research has some managerial implications for practitioners. Given that WLB serves as predictor of positive attitudes and behaviour of employees [3], organisational leaders are invited to design some strategies and take some initiatives, which would be concerned with eliminating or reducing the factors that lower WLB and with enhancement of factors that seem to boost WLB, especially in the period of the COVID-19 pandemic. Several aspects that might be taken into consideration by practitioners are provided below.

Firstly, organisations are encouraged to give more control to employees over their work processes. In order to have a real job control, employees require a high skill level and creativity [91] and this can be achieved by developing their skills, for instance providing training and mentorship programmes.

Secondly, the results suggest that the managers can enhance WLB through support. Line managers need to understand how employees' work and nonwork lives are constructed [20] and accordingly help them develop job-related skills and coping strategies, build employee networks, and provide opportunities for success [93]. During the crisis situation, like lockdown, when some of the employees felt lonely and detached from the employer, it was extremely important for them to feel the support of their managers [3]. As such, organisations ought to develop line managers' competencies how to deal with employees striving for a higher WLB.

Thirdly, as job autonomy referring to the possibility for the employees to freely choose their tasks, work schedule, and pace [91] serves as a significant antecedent of WLB, the organisations are encouraged to give more freedom to employees in the aspects related to their work.

Fourthly, the policy that "working after working hours" is a common business practice should be forgotten by organisations willing to foster their employees' WLB. Working hours beyond the normal schedule and overtime work tend to disrupt WLB and in turn might impair employee health. Trying to avoid the negative consequences, organisations are invited to implement fair working hours and workload policy, supporting their employee well-being [94].

Summing up, the complex of actions with respect to the development of employees and line managers, involving employees in decision-making, promoting a more autonomous workplace, creating work environment with lower job demands and fostering an organisational culture of "no work after working hours" might create a synergic effect and increase WLB as such.

\subsection{Limitations and directions for future research}

This research has some shortcomings that might be addressed in future research.

The first concern is related to self-reported nature of the data regarding antecedents of WLB. The future research might also be based on the collection of data from other sources, such as supervisor ratings of workload, co-worker ratings of support, or partnerrated perceptions of family demands [23].

The second concern is related to the respondents' profile. In this research, the respondents were mainly women. The danger here is that women working remotely might report higher WLB, which is achieved at the cost of lower income and prospects [89]. However, this does not correspond to the notion of employee well-being [94]. Thus, further studies are encouraged to select either to conduct a research with women only or to have a more heterogeneous sample with more or less equal gender representation. A comparative gender study could contribute to disclosure of differences and / or similarities among gender WLB and its antecedents.

The third concern refers to the sample in terms of potential respondents who had the possibility to receive an invitation to take part in the research. It is obvious that not all employees who worked remotely might be users of social media. Therefore, for future studies, the business organisations and networks of employers could be invited to act as potential mediators between the researchers and potential respondents helping to spread the information and questionnaires to employees through emails.

The fourth concern deals with the character of work as it was neglected in the current research. For further research it would be worth to include, for instance, data about industries the respondents worked in; work position (managerial or non-managerial); or organisation of work (in teams or individually). Such data could allow for obtaining a more complex view on the working environment and thus the conclusions could tackle various aspects of people management at work and their WLB.

The fifth concern refers to the captured antecedents of WLB. As the WLB antecedents could differ in nature, further research might include other job demands and resources, and family demands and 
resources linking them to WLB while working remotely.

Summing up, the central argument for future research refers to the notion that while analysing WLB, a more holistic and nuanced understanding of contemporary life domain and contemporary work domain should be addressed.

\section{Acknowledgments}

The authors have no acknowledgments

\section{Author contributions}

CONCEPTION: Živilè Stankevičiūtė

METHODOLOGY: Živile Stankevičiūtè

DATA COLLECTION: Svetlana Kunskaja

INTERPRETATION OR ANALYSIS OF DATA:

Živilè Stankevičiūtė and Svetlana Kunskaja

PREPARATION OF THE MANUSCRIPT: Živile

Stankevičiūte and Svetlana Kunskaja

REVISION FOR IMPORTANT INTELECTUAL CONTENT: Živilè Stankevičiūte and Svetlana Kunskaja

SUPERVISION: Živile Stankevičiūtè

\section{References}

[1] Waizenegger L, McKenna B, Cai W, Bendz T. An affordance perspective of team collaboration and enforced working from home during COVID-19. European Journal of Information Systems. 2020;29(4):429-42.

[2] Ratten V. Coronavirus (Covid-19) and entrepreneurship: changing life and work landscape. Journal of Small Business \& Entrepreneurship. 2020;32(5):503-16.

[3] Kumar R, Mokashi UM. COVID-19 and Work-Life Balance: What about Supervisor Support and Employee Proactiveness? Annals of Contemporary Developments in Management \& HR. 2020;2(4):1-9.

[4] Allen TD, Merlo K, Lawrence RC, Slutsky J, Gray CE. Boundary management and work-nonwork balance while working from home. Applied Psychology: An International Review. 2021;70(1):60-8.

[5] Allen TD, French KA, Dumani S, Shockley KM. A cross-national meta-analytic examination of predictors and outcomes associated with work-family conflict. Journal of Applied Psychology. 2020;105(6):539-76.

[6] Grincevičienè N. The Effect of the Intensity of Telework Use on Employees' Work-Life Balance. Vilnius : Vilnius University Press. 2020;21.

[7] Raišienè AG, Rapuano V, Varkulevičiūte K, Stachová K. Working from Home-Who Is Happy? A Survey of Lithuania's Employees during the COVID-19 Quarantine Period. Sustainability. 2020;12(13):1-21.
[8] Allen TD, Golden T, Shockley KM. How effective is telecommuting? Assessing the status of our scientific findings. Psychological Science in the Public Interest. 2015; 16(2):40-68.

[9] Kossek EE, Lautsch BA, Eaton SC. Telecommuting, control, and boundary management: Correlates of policy use and practice, job control, and work-family effectiveness. Journal of Vocational Behavior. 2006;68(2): 347-67.

[10] Greenhaus JH, Kossek EE. The Contemporary Career: A Work-Home Perspective. Annual Review of Organizational Psychology and Organizational Behavior. 2014;1:361-88.

[11] Allen TD, Cho E, Meier LL. Work-family boundary dynamics. Annual Review of Organizational Psychology and Organizational Behavior. 2014;1:99-121.

[12] Nakrošienė A, Bučiūnienè I, Goštautaite B. Working from home: characteristics and outcomes of telework. International Journal of Manpower. 2019;40(1):87-101.

[13] Lapierre LM, Van Steenbergen EF, Peeters MC, Kluwer ES. Juggling work and family responsibilities when involuntarily working more from home: A multiwave study of financial sales professionals. Journal of Organizational Behavior. 2016;37(6):804-22.

[14] Di Martino V, Wirth L. Telework: A new way of working and living. Int'l Lab Rev. 1990;129:529.

[15] Wang B, Liu Y, Qian J, Parker SK. Achieving Effective Remote Working During the COVID-19 Pandemic: A Work Design Perspective. Applied psychology: an international review. 2021;70(1):16-59.

[16] Putri A, Amran A. Employees' Work-Life Balance Reviewed From Work From Home Aspect During COVID19 Pandemic. International Journal of Management Science and Information Technology. 2021;1(1):30-4.

[17] Valcour M. Work-based resources as moderators of the relationship between work hours and satisfaction with work-family balance. Journal of Applied Psychology. 2007;92(6):1512-23

[18] Haar JM. Testing a new measure of work-life balance: A study of parent and non-parent employees from New Zealand. International Journal of Human Resource Management. 2013;24(17/18):3305-24.

[19] Casper WJ, de Hauw S, Wayne JH, Greenhaus JH. The jingle-jangle of work-non work balance: A comprehensive review of its meaning and measurement. Journal of Applied Psychology. 2018;103(2):182-214.

[20] Kelliher C, Richardson J, Boiarintseva G. All of work? All of life? Reconceptualising work-life balance for the 21st century. Human Resource Management Journal. 2019;29:97-112.

[21] Delecta P. Work life balance. International Journal of Current Research. 2011;3(4):186-9.

[22] Greenhaus JH, Collins KM, Shaw JD. The relation between work-family balance and quality of life. Journal of Vocational Behavior. 2003;63(3):510-31.

[23] Haar JM, Sune A, Russo M, Ollier-Malaterre A. A crossnational study on the antecedents of work-life balance from the fit and balance perspective. Social Indicators Research. 2019;142(1):261-82.

[24] Bhende P, Mekoth N, Ingalhalli V, Reddy YV. Quality of Work Life and Work-life Balance. Journal of Human Values. 2020;26(3):256-65. 
[25] Haider S, Jabeen S, Ahmad J. Moderated mediation between work life balance and employee job performance: The role of psychological wellbeing and satisfaction with coworkers. Journal of Work and Organizational Psychology. 2018;34(1):29-37.

[26] Hofmann V, Stokburger-Sauer NE. The impact of emotional labor on employees' work-life balance perception and commitment: A study in the hospitality industry. International Journal of Hospitality Management. 2017;65:47-58.

[27] Ola OO, John WO, Simeon OA, Mutiu OA. Impact of Work Life Balance on the Social Life of Workers Living in Lagos Metropolitan Borders. Annals of Contemporary Developments in Management \& HR. 2019;1(2):50-9.

[28] Dizaho KE, Muhammad Othman FBM. Antecedents of work life balance and its impact on loyalty, satisfaction and performance. Proceeding of the Global Conference on Business, Economics and Social Sciences. [2013 June 25-26, Kuala Lumpur]. Available from: https://bit.ly/35DARDo

[29] AlHazemi AA, Ali W. The notion of work life balance, determining factors, antecedents and consequences: a comprehensive literature survey. International Journal of Academic Research and Reflection. 2016;4(8):74-85.

[30] Haar J, Brougham D. Work antecedents and consequences of work-life balance: A two sample study within New Zealand. The International Journal of Human Resource Management. 2020;1-24.

[31] Tavassoli T, Sune A. A national study on the antecedents and outcomes of work-life balance in Iran. People: International Journal of Social Sciences. 2018;3(3):1616-36.

[32] Hammer LB, Cullen JC, Neal, MB, Sinclair RR, Shafiro MV. The longitudinal effects of work-family conflict and positive spillover on depressive symptoms among dualearner couples. Journal of Occupational Health Psychology. 2005;10(2):138-54.

[33] Butler AB, Grzywacz JG, Bass BL, Linney KD. Extending the demands-control model: A daily diary study of job characteristics, work-family conflict and work-family facilitation. Journal of Occupational Health Psychology. 2005;78:155-69.

[34] Nordenmark M, Vinberg S, Strandh M. Job control and demands, work-life balance and wellbeing among selfemployed men and women in Europe. Society, Health \& Vulnerability. 2012;3(1):1-18.

[35] Byron K. A meta-analytic review of work-family conflict and its antecedents. Journal of Vocational Behavior. 2005;67(2):169-98.

[36] O'Driscoll M, Brough P, Biggs A. Work-Family Balance: Concepts, Implications and Interventions. Occupational Health Psychology: European Perspectives on Research, Education and Practice. 2007; pp. 193-217.

[37] Brough P, O'Driscoll, M, Kalliath, T. Work-Family Conflict and Facilitation: Achieving work-family balance. Advances in Organizational Psychology: An Asia Pacific Perspective. 2007; pp. 73-92.

[38] Steiber N. Reported levels of time-based and strain-based conflict between work and family roles in Europe: A multilevel approach. Social Indicators Research. 2009;93(3): 469-88.

[39] Kasbuntoro, Irma D, Maemunah S, Mahfud I, Fahlevi M, Parashakti RD. Work-Life Balance and Job Satisfaction: A Case Study of Employees on Banking Companies in
Jakarta. International Journal of Control and Automation. 2020;13(4):439-51.

[40] Yildirim D, Aycan Z. Nurses' work demands and work-family conflict: A questionnaire survey. International Journal of Nursing Studies. 2008;45(9):1366-78.

[41] Sturges J, Guest D. Working to live or living to work? Work/life balance early in the career. Human Resource Management Journal. 2004;14(4):5-20.

[42] Mellner C, Aronsson G, Kecklund, G. Boundary Management Preferences, Boundary Control, and Work-Life Balance among Full-Time Employed Professionals in Knowledge-Intensive, Flexible. Nordic Journal of Working Life Studies. 2014;4(4):7-23.

[43] Bjärntoft S, Hallman DM, Mathiassen SE, Larsson, Jahncke H. Occupational and Individual Determinants of Work-life Balance among Office Workers with Flexible Work Arrangements. International Journal of Environmental Research and Public Health. 2020;17(4):1-15.

[44] Haar JM, Spell C. How does distributive justice affect work attitudes? The moderating effects of autonomy. International Journal of Human Resource Management. 2009;20(8):1827-42.

[45] Thompson CA, Prottas DJ. Relationships among organizational family support, job autonomy, perceived control, and employee well-being. Journal of Occupational Health Psychology. 2006;11(1):100-18.

[46] Vera M, Martínez IM, Lorente L, Chambel MJ. The role of co-worker and supervisor support in the relationship between job autonomy and work engagement among Portuguese nurses: A multilevel study. Social Indicators Research. 2016;126(3):1143-56.

[47] Boyar SL, Maertz CP, Mosley DC, Carr JC. The impact of work/family demand on work-family conflict. Journal of Managerial Psychology. 2008;23(3):215-35.

[48] Carvalho VS, Chambel MJ. Work-to-family enrichment and employees' well-being: High performance work system and job characteristics. Social Indicators Research. 2014;119(1):373-87.

[49] Gordon S, Adler H, Day J, Sydnor S. Perceived supervisor support: A study of select-service hotel employees. Journal of hospitality and Tourism Management. 2019;38:82-90.

[50] Aydın E, Kalemci Tüzün I. Organizational support sources and job performance relations: what about occupational commitment? An International Journal of Tourism and Hospitality Research. 2019;30(3):379-89.

[51] Gigliotti R, Vardaman J, Marshall DR, Gonzalez K. The role of perceived organizational support in individual change readiness. Journal of Change Management. 2019;19(2): 86-100.

[52] Umrani WA, Afsar B, Khan M, Ahmed U. Addressing the issue of job performance among hospital physicians in Pakistan: The role of job security, organizational support, and job satisfaction. Journal of Applied Biobehavioral Research. 2019;24(3):1-17.

[53] Winarto Y, Chalidyanto D. Perceived supervisor support and employee job satisfaction in private hospital. Eurasian Journal of Biosciences. 2020;14(2):2793-7.

[54] Hammer LB, Kossek EE, Yragui NL, Bodner TE, Hanson GC. Development and validation of a multidimensional measure of family supportive supervisor behaviors. Journal of Management. 2009;18(3):285-96. 
[55] Russo M, Buonocore F, Carmeli A, Guo L. When family supportive supervisors meet employees' need for caring: Implications for work-family enrichment and thriving. Journal of Management. 2015;4(4):1678-702.

[56] Newman A, Nielsen I, Smyth R, Hooke A. Examining the relationship between workplace support and life satisfaction: The mediating role of job satisfaction. Social Indicators Research. 2015;120(3):769-81.

[57] Lambert SJ. Added benefits: The link between work-life benefits and organizational citizenship behavior. Academy of Management Journal. 2000;43(5):801-15.

[58] Ferguson M, Carlson D, Zivnuska S, Whitten D. Support at work and home: The path to satisfaction through balance. Journal of Vocational Behavior. 2012;80(2):299-307.

[59] Bradley L, McDonald P, Cox S. The critical role of coworker involvement: An extended measure of the workplace environment to support work-life balance. Journal of Management \& Organization. 2019; pp. 1-22.

[60] Hegtvedt KA, Clay-Warner J, Ferrigno ED. Reactions to injustice: Factors affecting workers' resentment toward family-friendly policies. Social Psychology Quarterly. 2002;65(4):386-401.

[61] Lu J, Siu O, Spector P, Shi K. Antecedents and outcomes of a fourfold taxonomy of work-family balance in Chinese employed parents. Journal of Occupational Health Psychology. 2009;14(2):182-92.

[62] Michel J, Kotrba L, Mitchelson J, Clark M, Baltes B. Antecedents of work-family conflict: A meta-analytic review. Journal of Organizational Behavior. 2011;32:689-725.

[63] Spell CS, Arnold T. An appraisal perspective of justice, structure, and job control as antecedents of psychological distress. Journal of Organizational Behavior. 2007;28(6): 729-51. doi:10.1002/job.441

[64] Millán A, Millán JM, Caçador-Rodrigues L. Disclosing 'masked employees' in Europe: job control, job demands and job outcomes of 'dependent self-employed workers'. Small Bus Econ. 2020;55:461-74.

[65] Ng LP, Chen IC, Ng HF, Lin BY, Kuar LS. Influence of job demands and job control on work-life balance among Taiwanese nurses. The Journal of Nursing Management. 2017;25(6):438-48.

[66] Yang N, Chen CC, Choi J, Zou Y. Sources of work-family conflict: A Sino-US comparison of the effects of work and family demands. Academy of Management Journal. 2000;43(1):113-23.

[67] Voydanoff P. Toward a conceptualization of perceived work-family fit and balance: A demands and resources approach. Journal of Marriage and Family. 2005;67(4): 822-36.

[68] Russell H, O'Connell PJ, McGinnity F. The impact of flexible working arrangements on work-life conflict and work pressure in Ireland. Gender, Work \& Organization. 2009;16(1):73-97. https://doi.org/10.1111/j.14680432.2008.00431.x

[69] Zhang S, Moeckel R, Moreno AT, Shuai B, Gao J. A work-life conflict perspective on telework. Transportation Research Part A: Policy and Practice. 2020;141:51-68.

[70] Russo M, Shteigman A, Carmeli A. Workplace and family support and work-life balance: Implications for individual psychological availability and energy at work. The Journal of Positive Psychology. 2016;11(2):173-88.
[71] Andrew A, Cattan S, Costa Dias M, Farquharson C, Kraftman L, Krutikova S. How are mothers and fathers balancing work and family under lockdown? The Institute for Fiscal Studies; 2020. Available from: https://bit.ly/3cWC1OK

[72] Carlson DL, Petts R, Pepin JR. Changes in Parents' Domestic Labor During the COVID-19 Pandemic. 2020. Available from: https://doi.org/10.31235/osf.io/jy8fn

[73] Collins C, Landivar LC, Ruppanner L, Scarborough WJ. COVID-19 and the gender gap in working hours. Gender, Work \& Organization. 2021;28(S1):101-12.

[74] Craig L, Churchill B. 2020. Dual-earner parent couples' work and care during COVID-19. Gender, Work \& Organization. 2021;28(S1):66-79.

[75] Manzo LKC, Minello A. Mothers, childcare duties, and remote working underCOVID-19 lockdown in Italy: Cultivating communities of care. Dialogues in Human Geography. 2020;10(2):120-3.

[76] Qian Y, Fuller S.COVID-19 and the gender employment gap among parents of young children, Canadian Public Policy. 2020;46(2):89-101.

[77] Esteves L, Ashencaen Crabtree S, Hemingway A. Impacts of C-19 lockdown on the work-life balance of BU academics - Preliminary results. Working Paper. Poole, England: Bournemouth University; 2020. Available from: https:// bit.ly/3cZE5Ft

[78] Etikan I, Musa SA, Alkassim RS. Comparison of convenience sampling and purposive sampling. American Journal of Theoretical and Applied Statistics. 2016;5(1):1-4.

[79] Haar JM. Testing a new measure of work-life balance: A study of parent and non-parent employees from New Zealand. The International Journal of Human Resource Management. 2013;24(17):3305-24.

[80] Knudsen HK, Aaron Johnson J, Martin JK, Roman PM. Downsizing survival: The experience of work and organizational commitment. Sociological Inquiry. 2003;73(2): 265-83.

[81] Lambert SJ. Added benefits: The link between work-life benefits and organizational citizenship behavior. Academy of management Journal. 2000;43(5):801-15.

[82] $\mathrm{Li} \mathrm{YQ}$, Liu $\mathrm{CH}$. The power of coworkers in service innovation: the moderating role of social interaction. The International Journal of Human Resource Management. 2019;30(12):956-1976.

[83] Spector PE, Allen TD, Poelmans SA, Lapierre LM, Cooper CL, MICHAEL OD,... \& WIDERSZAL-BAZYL M.A.R.I.A. Cross-national differences in relationships of work demands, job satisfaction, and turnover intentions with work-family conflict. Personnel Psychology. 2007;60(4): 805-35.

[84] Brislin RW. Back-translation for cross-cultural research. J Cross Cult Psychol. 1970;1:185-216. doi: 10.1177/135910 457000100301

[85] Yong AG, Pearce S. A beginner's guide to factor analysis: Focusing on exploratory factor analysis. Tutorials in Quantitative Methods for Psychology. 2013;9(2):79-94.

[86] Nunnally JC. Psychometric Theory: 2d Ed. McGraw-Hill 1978.

[87] López-Igual P, Rodríguez-Modroño P. Who is teleworking and where from? Exploring the main determinants of telework in Europe. Sustainability. 2020;12(21):8797. 
[88] Thébaud S, Kornrich S, Ruppanner L. Great housekeeping, great expectations: Gender and housework norms. Sociological Methods \& Research. 2019, 1-29. https://doi.org/ $10.1177 / 0049124119852395$

[89] Rodríguez-Modroño P, López-Igual P. Job Quality and Work-Life Balance of Teleworkers. International Journal of Environmental Research and Public Health. 2021;18(6):3239.

[90] Othman N, Yusef SAM, Osman WRS. A conflict between professional vs. domestic life? Understanding the use of ICT in teleworking for balance in work and family units. 2009.

[91] De Clercq D, Brieger SA. When Discrimination is Worse, Autonomy is Key: How Women Entrepreneurs Leverage Job Autonomy Resources to Find Work-life Balance. Journal of Business Ethics. 2021;1-18.
[92] Chiang FF, Birtch TA, Kwan HK. The moderating roles of job control and work-life balance practices on employee stress in the hotel and catering industry. International Journal of Hospitality Management. 2010;29(1):25-32.

[93] Talukder AKM, Vickers M, Khan A. Supervisor support and work-life balance: Impacts on job performance in the Australian financial sector. Personnel Review. 2018.

[94] Guest DE. Human resource management and employee well-being: Towards a new analytic framework. Human Resource Management Journal. 2017;27(1):22-38. 